\title{
IDENTIFIKASI FAKTOR PRIORITAS MOTIVASI DAN PRESTASI TENAGA KERJA KONSTRUKSI DALAM MENGOPTIMALKAN PENGGUNAAN TENAGA KERJA LOKAL DI TIMOR LESTE
}

\author{
Tonizio Amaral Lopes Da Cruz ${ }^{1}$, Wahyu Indra Sakti \\ ${ }^{1}$ Mahasiswa Magister Teknik Sipil Universitas Tarumanagara \\ Surel: tonizioamaral@gmail.com \\ ${ }^{2}$ Dosen Magister Teknik Sipil Universitas Tarumanagara \\ Surel: wahyusaidi@gmail.com
}

\begin{abstract}
Human resources $(H R)$ is an important factor in the process of implementing construction projects. In a construction project several levels of human resources can be found, starting from the project manager to the lowest level, which is labor. The characteristics of the human resources itself must be planned with proper HR management. The State of Timor Leste is one of the developing countries in Southeast Asia that is still in need of the role of qualified human resources. The construction workforce used today is still highly dependent on neighboring countries. This dependence is caused by the lack of work motivation of the construction workforce and the work performance that was previously achieved by the local workforce. The purpose of this study is to determine the motivational factors and work performance of construction workers, as well as solutions to increase motivation and work performance of construction workers and to increase the use of local labor in the state of Timor Leste. Data collection was done through questionnaires distributed to respondents which were staffs of foreign workers recruiting agencies or companies that had brought in foreign construction workers. The result showed that there were 5 factors each determining work motivation and work performance of construction workers. Work performance factors are technical skills, work experience, work quality, work quantity, and diligence, while work motivation factors are the reward system received, needs (biological and psychological), interests, hopes for the future, and regulated by the existence of punishment.
\end{abstract}

Keywords: Work Motivation, Work Performance, Human Resource Management.

\begin{abstract}
ABSTRAK
Sumber daya manusia (SDM) merupakan salah satu faktor penting dalam proses pelaksanaan proyek konstruksi. Dalam suatu proyek konstruksi terdapat beberapa tingkatan sumber daya manusia, mulai dari manajer proyek sampai dengan tingkat paling bawah yaitu tenaga kerja. Karaktristik SDM itu sendiri harus direncanakan dengan manajemen SDM yang baik dan benar. Negara Timor Leste merupakan salah satu negara berkembang di Asia Tenggara yang terbilang masih sangat membutuhkan peran SDM yang berkualitas. Tenaga kerja konstruksi yang digunakan sampai saat ini masih sangat bergantung kepada negara tetangga. Ketergantungan ini diakibatkan oleh kurangnya motivasi kerja tenaga konstruksi dan prestasi kerja yang pernah dicapai tenaga kerja lokal sebelumnya. Tujuan dari penelitian ini adalah untuk mengetahui faktor-faktor motivasi dan prestasi kerja tenaga konstruksi, serta solusi untuk meningkatkan motivasi dan prestasi kerja tenaga konstruksi dan untuk memperbanyak penggunaan tenaga kerja lokal di Negara Timor Leste. Pengumpulan data dilakukan melalui survei kuesioner terhadap responden dari staf-staf perusahaan perekrutan tenaga asing atau perusahaan yang pernah mendatangkan tenaga kerja konstruksi asing. Hasil penelitian menunjukkan bahwa terdapat 5 faktor dari masingmasing motivasi kerja dan prestasi kerja tenaga konstruksi. Faktor prestasi kerja yaitu kemampuan teknis, pengalaman kerja, kualitas kerja, kuantitas kerja, kerajinan, sedangkan faktor motivasi kerja yaitu sistem imbalan yang diterima, kebutuhan (biologis maupun psikologis), minat, harapan-harapan akan masa depan dan dikendalikan dengan adanya hukuman.
\end{abstract}


Kata Kunci: Motivasi Kerja, Prestasi Kerja, Manajemen Sumber Daya Manusia.

\section{PENDAHULUAN}

Pada era globalisasi seperti sekarang ini, permasalahan tentang sumber daya manusia (tenaga kerja) dalam suatu perusahaan menuntut untuk lebih diperhatikan, sebab secanggih apapun teknologi yang dipergunakan dalam suatu perusahaan serta sebesar apapun modal yang diputar perusahaan, tenaga kerja tetap merupakan asset yang paling utama dalam kehidupan perusahaan karena tanpa adanya pekerja maka peralatan dan modal tidak mungkin akan dapat di pergunakan secara maksimal. Tenaga kerja merupakan sebagai salah satu elemen utama dalam suatu sistem kerja, sehingga tenaga kerja masih sangat di butuhkan oleh setiap perusahaan.

Timor Leste adalah sebuah negara yang terletak di bagian timur Pulau Timor, Asia Tenggara. Pulau Timor yang berada di sebelah utara benua Australia ini dimiliki oleh dua negara yaitu Republik Indonesia dan Republik Demokratis Timor Leste. Sebelum merdeka, Timor Leste merupakan salah satu Provinsi di Republik Indonesia dengan nama Provinsi Timor Timur. Timor Leste secara resmi merdeka dari Indonesia pada tanggal 20 Mei 2002 dan menetapkan Kota Dili sebagai Ibukotanya.

Negara Timor Leste merupakan salah satu negara berkembang di Asia Tenggara yang terbilang masih sangat membutuhkan peran SDM yang berkualitas. Tenaga kerja konstruksi yang digunakan sampai saat ini masih sangat bergantung kepada negara tetangga seperti Indonesia, Filipina, Malaysia, dan Singapura. Ketergantungan ini diakibatkan oleh kurangnya motivasi tenaga kerja konstruksi dan prestasi yang pernah dicapai tenaga kerja lokal sebelumnya. Hal ini yang menyebabkan kontraktor (perusahaan perekrutan tenaga kerja) di negara Timor Leste cenderung lebih memilih mendatangkan tenaga kerja dari negara tetangga. Walaupun dalam kenyataannya, tidak ada perbedaan skills dan job behavior (kemampuan untuk menyelesaikan suatu pekerjaan) yang dimiliki oleh tenaga kerja lokal dengan tenaga kerja yang didatangkan.

Menurut Uno (2007), motivasi dapat diartikan sebagai dorongan internal dan eksternal dalam diri seseorang yang diindikasikan dengan adanya hasrat dan minat, dorongan dan kebutuhan, harapan dan cita-cita, penghargaan dan penghormatan. Adapun menurut Wibowo (2010) mengemukakan bahwa motivasi merupakan dorongan terhadap serangkaian proses perilaku manusia pada pencapaian tujuan. Sedangkan elemen yang terkandung dalam motivasi meliputi unsur membangkitkan, mengarahkan, menjaga, menunjukkan intesitas, bersifat terus menerus dan adanya tujuan.

Prestasi kerja merupakan salah satu indikator yang tidak kalah penting dalam manajemen sumber daya manusia. Menurut Hasibuan (2008), prestasi kerja adalah suatu hasil kerja yang dicapai seseorang dalam melaksanakan tugas-tugas yang dibebankan kepadanya yang didasarkan atas kecakapan dan kesungguhan serta waktu.

Penelitian ini dilakukan untuk mengetahui apa saja faktor motivasi kerja dan prestasi kerja tenaga konstruksi di Negara Timor Leste dalam memperbanyak penggunaan tenaga kerja lokal. Penelitian ini dilakukan pada proyek konstruksi XYZ di Negara Timor Leste. Berdasarkan latar belakang di atas, maka pokok permasalahan dalam penelitian ini adalah apa saja faktor-faktor prioritas dan solusi untuk meningkatkan motivasi kerja dan prestasi kerja, serta bagaimana cara untuk meningkatkan penggunaan tenaga konstruksi lokal di Negara Timor Leste. 
Berdasarkan rumusan masalah di atas, maka tujuan dari penelitian ini adalah untuk mengetahui faktor-faktor dan solusi untuk meningkatkan motivasi kerja dan prestasi kerja serta cara untuk memperbanyak atau meningkatkan penggunaan tenaga konstruksi lokal di Negara Timor Leste.

Batasan penelitian bertujuan untuk membatasi pembahasan pada pokok penelitian, sehingga penelitian ini terbatas pada:

1. Objek penelitian yang ditinjau hanya berada di Distrik Dili, Distrik Baucau dan Distrik Same, Negara Timor Leste.

2. Pengamatan yang dilakukan khusus untuk tenaga konstruksi.

Adapun manfaat yang ingin dicapai atau diperoleh dari penelitian ini antara lain adalah sebagai berikut:

1. Manfaat teoritis, penelitian ini dapat memberikan informasi mengenai faktor-faktor yang mempengaruhi motivasi dan prestasi kerja tenaga konstruksi.

2. Manfaat praktis, penelitian ini diharapkan menjadi gambaran mengenai hal-hal apa saja yang harus diperhatikan dan diperbaiki dalam meningkatkan motivasi prestasi tenaga konstruksi. 


\section{TINJAUAN PUSTAKA}

\section{Manajemen Sumber Daya Manusia}

Menurut Robbins dan Judge (2007), management is the process of getting activities completed efficiently and effectively with the through other people (Manajemen adalah suatu proses untuk memperoleh kegiatan menyeluruh secara efisien dan efektif dengan cara melalui orang lain).

\section{Pengembangan Sumber Daya Manusia sebagai Aset Perusahaan}

Pengembangan sumber daya manusia dimaksudkan untuk meningkatkan keterampilan atau kemampuan manusia dalam melakukan berbagai kegiatan di dalam masyarakat. Pengembangan SDM terkait erat dengan usaha peningkatan taraf hidup. Banyak dari kita yang menyelesaikan permasalahan SDM dengan menekankan pada segi peningkatan keterampilan dan kemampuan (untuk melakukan suatu pekerjaan tertentu), sedangkan isu taraf hidup, kesejahteraan dan kepuasan kerja sering diabaikan karena dianggap mengikuti peningkatan kemampuan pegawai. Padahal pendapat tersebut belum tentu benar. Pengembangan SDM berawal dan dimulai dalam keluarga, kemudian ditingkatkan melalui pendidikan dan latihan formal, yang akhirnya dikembangkan dalam masyarakat, khususnya di lingkungan pekerjaan. Orang tua memberikan petunjuk, nasihat, dan meluruskan kebiasaan cara kerja pada anak-anaknya. Demikian juga orang dewasa dalam keluarga hidup dengan aturan dan tata kebiasaan yang banyak ditiru oleh orang yang lebih muda. Cara itu sudah berlangsung sejak permulaan peradaban manusia dan masih relevan untuk masa kini dan yang akan datang (Saidi dan Halim, 2007).

\section{Proyek Konstruksi}

Proyek konstruksi menurut Ervianto (2005) adalah satu rangkaian kegiatan yang hanya satu kali dilaksanakan dan umumnya berjangka pendek. Dalam rangkaian kegiatan tersebut, ada suatu proses yang mengelola sumber daya proyek menjadi suatu hasil kegiatan yang berupa bangunan.

\section{Tenaga Kerja}

Menurut Subri (2003), tenaga kerja adalah penduduk dalam usia kerja (berusia 15-64 tahun) atau jumlah penduduk dalam suatu negara yang dapat memproduksi barang dan jasa jika ada permintaan terhadap tenaga kerja mereka dan jika mereka mau berpartisipasi dalam aktivitas tersebut.

\section{Motivasi Kerja}

Motivasi dapat didefinisikan sebagai suatu keadaan dalam diri seseorang yang mendorong, mengaktifkan atau menggerakkan dan yang mengarahkan perilaku ke arah tujuan (Pujadi 2007). Motivasi berasal dari kata motif yang berarti dorongan atau daya penggerak yang ada dalam diri seseorang yang menyebabkan seseorang melakukan suatu tindakan atau aktivitas (Notoatmodjo, 2007).

Menurut Siagian (2008), motivasi adalah daya pendorong yang mengakibatkan seseorang mau dan rela untuk mengerahkan kemampuan dalam bentuk keahlian atau keterampilan tenaga dan waktunya untuk menyelenggarakan berbagai kegiatan yang menjadi tanggung jawabnya dan menuaikan kewajibannya dalam rangka pencapaian tujuan dari berbagai sasaran yang telah ditentukan sebelumnya. Selain itu, menurut Saidi dan Halim (2007), motivasi adalah dorongan dari dalam diri manusia yang timbul akibat adanya rangsangan (stimulus) dari dalam lingkungan yang dihadapinya, sehingga menggerakkan kemauan kuat seseorang untuk melakukan tindakan tertentu agar tujuan yang diharapkan dapat tercapai. 



\section{Prestasi Kerja}

Menurut Husnan (2002), prestasi kerja dapat ditafsirkan sebagai arti pentingnya suatu pekerjaan, tingkat keterampilan yang diperlukan, kemajuan dan tingkat penyelesaian suatu pekerjaan. Hariandja (2002) mendefinisikan prestasi kerja merupakan hasil kerja yang dihasilkan oleh karyawan atau perilaku nyata yang ditampilkan sesuai dengan peranannya dalam organisasi.

Menurut Wahyudi (2002) secara umum penilaian prestasi kerja dapat diartikan sebagai suatu evaluasi yang dilakukan secara periodik dan sistematis tentang prestasi kerja atau jabatan (job specification) seorang tenaga kerja, termasuk potensi pengembangannya. Prestasi kerja merupakan proses tingkat mengukur dan menilai tingkat keberhasilan seseorang dalam pencapaian tujuan.

Menurut Mathis dan Jackson (2001), meskipun kepuasan kerja itu menarik dan penting, hal yang paling mendasar adalah pengaruh kepuasan kerja terhadap organisasi yang akan mempengaruhi kinerja karyawan. Menurut Simamora (2004), penilaian kinerja adalah proses yang dipakai oleh organisasi untuk mengevaluasi pelaksanaan kerja individu karyawan.

\section{METODE PENELITIAN}

Penelitian ini dilakukan berdasarkan prosedur yang dikemukakan oleh Arikunto (2003), yaitu sebagai berikut:

1. Penelitian dimulai dengan pemilihan masalah.

2. Melakukan studi pendahuluan dengan maksud untuk mencari informasi yang diperlukan oleh peneliti agar masalah menjadi jelas kedudukannya.

3. Merumuskan masalah agar penelitian dapat dilaksanakan sebaik-baiknya, serta jelas harus memulai dari mana.

4. Merumuskan anggapan dasar atau sesuatu yang diyakini kebenarannya oleh peneliti yang akan berfungsi sebagai acuan penelitian.

5. Menentukan hipotesis atau kebenaran sementara yang ditentukan oleh peneliti, tetapi masih harus dibuktikan kebenarannya.

6. Memilih pendekatan serta menentukan tipe penelitian yang akan digunakan.

7. Menentukan variabel dan sumber data penelitian.

8. Menentukan dan menyusun instrumen penelitian.

9. Mengumpulkan data menggunakan instrumen penelitian yang sudah ditentukan.

10. Menganalisis data yang sudah dikumpulkan.

11. Menarik kesimpulan berdasarkan hasil analisis data.

12. Menyusun laporan.

Penelitian ini dilakukan di Negara Timor Leste, pada tiga Distrik yang berbeda yaitu, Distrik Baucau (proyek pembangunan jalan raya), Distrik Dili (Proyek pembangunan gedung) dan Distrik Manufahi / Same (Proyek pembangunan irigasi).

Responden pada penelitian ini terbagi ke dalam kelompok responden praktisi dan responden pakar (expert). Responden praktisi adalah unsur-unsur kontraktor (perekrutan tenaga kerja) yang pernah mendatangkan tenaga kerja dari luar negeri, seperti project manager, site manager, dan site engineer, sedangkan responden pakar adalah akademisi dalam bidang manajemen sumber daya manusia. Untuk masing-masing kontraktor diambil 15 responden (kontraktor jalan berjumlah 15 responden, kontraktor irigasi berjumlah 15 orang dan kontraktor bangunan gedung berjumlah 15 orang), sehingga jumlah responden dalam penelitian ini adalah 45 responden. 
Pengumpulan data primer dilakukan dengan cara survei kuesioner, sedangkan data sekunder diperoleh melalui catatan dan atau dokumentasi perusahaan. Adapun variabel-variabel yang mempengaruhi motivasi kerja dan pretasi kerja tenaga konstruksi berdasarkan studi pustaka dan literatur yang sudah divalidasi oleh pakar, dapat dilihat pada tabel 1 dan tabel 2 di bawah ini:

\section{Tabel 1.}

\section{Variabel Penelitian Penelitian Prestasi Kerja}

\begin{tabular}{|c|c|}
\hline Variabel & Faktor-faktor prestasi kerja \\
\hline $\mathrm{X} 1$ & Faktor Kemampuan, kemampuan (knowledge + skill) \\
\hline $\mathrm{X} 2$ & $\begin{array}{l}\text { Faktor Motivasi: sikap (attitude), situasi (situation) kerja dan kondisi yang mendorong diri pekerja untuk berusaha mencapai } \\
\text { prestasi kerja secara maksimal. }\end{array}$ \\
\hline $\mathrm{X} 3$ & $\begin{array}{l}\text { Faktor Individu: Usaha (effort), Abilities dan Role/task perception, yaitu segala perilaku dan aktivitas yang dirasa perlu oleh } \\
\text { individu untuk menyelesaikan suatu pekerjaan. }\end{array}$ \\
\hline $\mathrm{X} 4$ & $\begin{array}{l}\text { Faktor lingkungan: Faktor lingkungan yaitu kondisi fisik, peralatan, waktu, material, supervisi, desain organisasi, pelatihan } \\
\text { dan keberuntungan. }\end{array}$ \\
\hline X5 & Kemampuan teknis: ilmu pengetahuan yang dimiliki, metode, teknik, dan peralatan yang dipergunakan. \\
\hline X6 & $\begin{array}{l}\text { Kemampuan konseptual: pada intinya individual tersebut memahami tugas, fungsi serta tanggung jawabnya sebagai seorang } \\
\text { karyawan. }\end{array}$ \\
\hline $\mathrm{X} 7$ & $\begin{array}{l}\text { Kemampuan hubungan interpersonal: Kemampuan untuk bekerja sama dengan orang lain, memotivasi karyawan, melakukan } \\
\text { negosiasi, dan lain-lain. }\end{array}$ \\
\hline $\mathrm{X} 8$ & $\begin{array}{l}\text { Kualitas kerja: dilihat dari akurasi, ketelitian dan kerapian karyawan dalam melaksanakan tugas pekerjaan, mempergunakan } \\
\text { dan memelihara alat-alat kerja, keterampilan dan kecakapan. }\end{array}$ \\
\hline X9 & $\begin{array}{l}\text { Kuantitas kerja: dilihat dari volume keluaran (output), target kerja dalam kuantitas dan kontribusi lain seperti menyelesaikan } \\
\text { pekerjaan tambahan berupa penambahan jam kerja (lembur). }\end{array}$ \\
\hline $\mathrm{X} 10$ & $\begin{array}{l}\text { Hubungan kerja: sikap terhadap sesama karyawan maupun terhadap atasannya, serta kesediaan menerima perubahan- } \\
\text { perubahan dalam bekerja. }\end{array}$ \\
\hline $\mathrm{X} 11$ & Kepemimpinan: cara atau gaya pemimpin dalam memimpin perusahaan. \\
\hline $\mathrm{X} 12$ & Kehati-hatian: perhatian karyawan terhadap keselamatan kerja, baik bagi dirinya sendiri maupun orang lain. \\
\hline $\mathrm{X} 13$ & $\begin{array}{l}\text { Kerajinan: kemampuan karyawan dalam melaksanakan tugas diluar pekerjaannya maupun adanya tugas baru, kecakapan } \\
\text { berpikir dan bertindak sebelum bekerja serta tingkat disiplin dalam menjalankan tugas dan kemampuan dalam mengeluarkan } \\
\text { inisiatif. }\end{array}$ \\
\hline $\mathrm{X} 14$ & Kesetiaan: Kesetiaan karyawan terhadap perusahaan dalam hal ini dapat dilihat dari masa kerja karyawan. \\
\hline $\mathrm{X} 15$ & Keandalan kerja: keandalan dalam melaksanakan tugas. \\
\hline $\mathrm{X} 16$ & Inisiatif: Kemampuan karyawan dalam menyelesaikan hal-hal baru. \\
\hline $\mathrm{X} 17$ & Sikap pekerja: Perilaku terhadap organisasi / lembaga atau atasan dan juga rekan kerja \\
\hline $\mathrm{X} 18$ & Mutu kerja: berkaitan dengan ketepatan waktu, keterampilan dan kepribadian dalam melakukan pekerjaan. \\
\hline X19 & Ketangguhan: Berkaitan dengan tingkat kehadiran, pemberian waktu libur, dan jadwal keterlambatan hadir di tempat kerja. \\
\hline $\mathrm{X} 20$ & Dukungan yang diterima. \\
\hline $\mathrm{X} 21$ & Pengalaman kerja (experience is the best of teacher). \\
\hline $\mathrm{X} 22$ & Keinginan untuk memiliki sesuatu (The desire for possession) \\
\hline $\mathrm{X} 23$ & Keinginan akan kekuasaan (The desire for power): ingin dipilih menjadi ketua atau kepala. \\
\hline $\mathrm{X} 24$ & Keinginan akan pengakuan (the desire for recognition): diakui dan dihormati \\
\hline $\mathrm{X} 25$ & Dorongan dari dalam diri yang timbul akibat adanya rangsangan dari dalam lingkungan yang dihadapinya. \\
\hline $\mathrm{X} 26$ & $\begin{array}{l}\text { Seseorang termotivasi atau tidak untuk melakukan sesuatu, banyak bergantung pada proses kognitif berupa persepsi. Persepsi } \\
\text { seseorang tentang dirinya sendiri akan mendorong dan mengarahkan perilaku seseorang untuk bertindak }\end{array}$ \\
\hline $\mathrm{X} 27$ & $\begin{array}{l}\text { Harga diri dan prestasi, faktor ini mendorong untuk mengarahkan individu (memotivasi) untuk berusaha agar menjadi pribadi } \\
\text { yang mandiri, kuat, dan memperoleh kebebasan serta mendapatkan status tertentu dalam lingkungan masyarakat, serta } \\
\text { mendorong individu untuk berprestasi. }\end{array}$ \\
\hline $\mathrm{X} 28$ & $\begin{array}{l}\text { Harapan-harapan akan masa depan. Harapan ini merupakan informasi objektif dari lingkungan yang mempengaruhi sikap dan } \\
\text { perasaan subjektif seseorang. Harapan merupakan tujuan dari perilaku. }\end{array}$ \\
\hline
\end{tabular}




\begin{tabular}{|c|c|}
\hline Variabel & Faktor-faktor motivasi kerja \\
\hline $\mathrm{X} 29$ & $\begin{array}{l}\text { Jenis dan sifat pekerjaan, dorongan untuk bekerja pada jenis dan sifat pekerjaan tertentu sesuai dengan objek pekerjaan } \\
\text { yang tersedia akan mengarahkan individu untuk menentukan sikap atau pilihan pekerjaan yang akan ditekuni. }\end{array}$ \\
\hline $\mathrm{X} 30$ & $\begin{array}{l}\text { Kelompok kerja dimana individu bergabung, kelompok kerja atau organisasi tempat dimana individu bergabung dapat } \\
\text { mendorong atau mengarahkan perilaku individu dalam mencapai suatu tujuan perilaku tertentu. }\end{array}$ \\
\hline $\mathrm{X} 31$ & $\begin{array}{l}\text { Sistem imbalan yang diterima, imbalan merupakan karakteristik atau kualitas dari objek pemuas yang dibutuhkan oleh } \\
\text { seseorang yang dapat mempengaruhi motivasi atau dapat mengubah arah tingkah laku dari satu objek ke objek lain yang } \\
\text { mempunyai nilai imbalan yang lebih besar. }\end{array}$ \\
\hline $\mathrm{X} 32$ & $\begin{array}{l}\text { Kebutuhan (need), melakukan aktivitas (kegiatan) karena adanya faktor-faktor kebutuhan baik biologis maupun } \\
\text { psikologis }\end{array}$ \\
\hline X33 & $\begin{array}{l}\text { Harapan (expectancy), dimotivasi oleh karena keberhasilan dan adanya harapan keberhasilan bersifat pemuasan diri } \\
\text { seseorang, keberhasilan dan harga diri meningkat dan menggerakkan seseorang ke arah pencapaian tujuan. }\end{array}$ \\
\hline $\mathrm{X} 34$ & Minat, minat adalah suatu rasa lebih suka dan rasa keinginan pada suatu hal tanpa ada yang menyuruh. \\
\hline $\mathrm{X} 35$ & Dorongan keluarga, dorongan keluarga merupakan salah satu faktor pendorong (reinforcing factors). \\
\hline $\mathrm{X} 36$ & $\begin{array}{l}\text { Lingkungan, lingkungan adalah tempat dimana seseorang tinggal. Lingkungan dapat mempengaruhi seseorang sehingga } \\
\text { dapat termotivasi untuk melakukan sesuatu. }\end{array}$ \\
\hline $\mathrm{X} 37$ & $\begin{array}{l}\text { Kebutuhan fisiologis (physiological). Kebutuhan untuk mempertahankan hidup dari kematian (makan, minum, } \\
\text { perumahan, pakaian, yang harus dipenuhi oleh seseorang dalam upayanya untuk mempertahankan diri dari kelaparan, } \\
\text { kehausan, kedinginan, kepanasan, dan sebagainya.) }\end{array}$ \\
\hline $\mathrm{X} 38$ & $\begin{array}{l}\text { Kebutuhan rasa aman (safety), setelah kebutuhan tingkat dasar terpenuhi, maka seseorang berusaha memenuhi } \\
\text { kebutuhannya yang lebih tinggi, yaitu kebutuhan akan rasa aman dan keselamatan. }\end{array}$ \\
\hline X39 & $\begin{array}{l}\text { Kebutuhan hubungan sosial (affiliation), Kebutuhan ini merupakan kebutuhan untuk hidup bersama dengan orang lain. } \\
\text { Kebutuhan ini hanya dapat terpenuhi bersama masyarakat, karena hanya orang lain yang dapat memenuhinya, bukan diri } \\
\text { sendiri. }\end{array}$ \\
\hline $\mathrm{X} 40$ & $\begin{array}{l}\text { Kebutuhan aktualisasi diri (self-actualization), kebutuhan aktualisasi diri merupakan tingkat kebutuhan yang paling } \\
\text { tinggi. Untuk memenuhi kebutuhan puncak ini biasanya seseorang bertindak bukan berdasarkan dorongan orang lain, } \\
\text { tetapi karena kesadaran dan keinginan diri sendiri. }\end{array}$ \\
\hline $\mathrm{X} 41$ & $\begin{array}{l}\text { harapan (expectancy theory), teori ini menyatakan bahwa kekuatan yang memotivasi seseorang bekerja giat dalam } \\
\text { melaksanakan pekerjaannya bergantung pada hubungan timbal balik antara apa yang ia inginkan dengan kebutuhan dari } \\
\text { hasil pekerjaan itu. }\end{array}$ \\
\hline $\mathrm{X} 42$ & $\begin{array}{l}\text { Keadilan (equity theory), ego manusia selalu mendambakan keadilan dalam pemberian hadiah maupun hukuman } \\
\text { terhadap setiap perilaku yang relative sama. Keadilan merupakan daya penggerak yang memotivasi semangat kerja } \\
\text { seseorang. }\end{array}$ \\
\hline $\mathrm{X} 43$ & $\begin{array}{l}\text { Pengukuhan (reinforcement theory), didasarkan atas hubungan sebab dan akibat perilaku dengan pemberian kompensasi. } \\
\text { Misalnya, promosi bergantung pada prestasi yang selalu dapat dipertahankan. bonus kelompok bergantung pada tingkat } \\
\text { produksi kelompok itu sendiri. Sifat ketergantungan tersebut bertautan dengan hubungan antara perilaku dan kejadian } \\
\text { yang mengikuti perilaku itu. }\end{array}$ \\
\hline $\mathrm{X} 44$ & $\begin{array}{l}\text { Need for achievement, merupakan kebutuhan untuk mencapai sukses, yang diukur berdasarkan standar kesempurnaan } \\
\text { dalam diri seseorang. Kebutuhan ini berhubungan erat dengan pekerjaan, dan mengarahkan tingkah laku pada usaha } \\
\text { untuk mencapai prestasi tertentu. }\end{array}$ \\
\hline $\mathrm{X} 45$ & $\begin{array}{l}\text { Need for affiliation, Merupakan kebutuhan akan kehangatan dalam hubungannya dengan orang lain. Kebutuhan ini } \\
\text { mengarahkan tingkah laku untuk mengadakan hubungan secara akrab dengan orang lain. }\end{array}$ \\
\hline $\mathrm{X} 46$ & $\begin{array}{l}\text { Need for power, Kebutuhan untuk menguasai dan memengaruhi orang lain. Kebutuhan ini menyebabkan orang yang } \\
\text { bersangkutan tidak atau kurang memperdulikan perasaan orang lain }\end{array}$ \\
\hline $\mathrm{X} 47$ & Memiliki tingkat tanggung jawab, berani mengambil dan memikul risiko, dan memiliki tujuan realistis \\
\hline $\mathrm{X} 48$ & Memiliki rencana kerja yang menyeluruh dan berjuang untuk merealisasikan tujuan \\
\hline X49 & Memanfaatkan umpan balik yang konkrit dalam semua kegiatan yang dilakukan \\
\hline $\mathrm{X} 50$ & $\begin{array}{l}\text { Existence (keberadaan). Kebutuhan ini merupakan kebutuhan seseorang untuk dapat terpenuhi dan terpeliharanya } \\
\text { keberadaan yang bersangkutan sebagai seorang manusia di tengah-tengah masyarakat atau perusahaan. }\end{array}$ \\
\hline $\mathrm{X} 51$ & Relatedness (kekerabatan). Kekerabatan merupakan keterkaitan antara seseorang dengan lingkungan sosial sekitarnya. \\
\hline $\mathrm{X} 52$ & $\begin{array}{l}\text { Growth (pertumbuhan) Kebutuhan akan pertumbuhan dan perkembangan ini merupakan kebutuhan yang berkaitan } \\
\text { dengan pengembangan potensi diri seseorang, seperti pertumbuhan kreativitas pribadi. }\end{array}$ \\
\hline X53 & Pada dasarnya tidak menyukai pekerjaan dan sebisa mungkin berusaha untuk menghindarinya \\
\hline X54 & Tidak menyukai pekerjaan, mereka harus dipakai, dikendalikan, atau diancam dengan hukuman untuk mencapai tujuan \\
\hline $\mathrm{X} 55$ & Karyawan akan menghindari tanggung jawab dan mencari perintah formal. \\
\hline X56 & Sebagian karyawan menempatkan keamanan diatas semua faktor lain terkait pekerjaan dan menunjukkan sedikit ambisi \\
\hline
\end{tabular}


Metode analisis data merupakan langkah yang paling menentukan dari suatu penelitian karena analisis data berfungsi untuk menyimpulkan hasil penelitian. Analisis dilakukan setelah feedback kuesioner dan diolah ke dalam bentuk angka, kemudian dilanjutkan dengan pengolahan. Adapun tahapan-tahapan yang dilakukan dapat dilihat pada gambar 1 berikut ini:

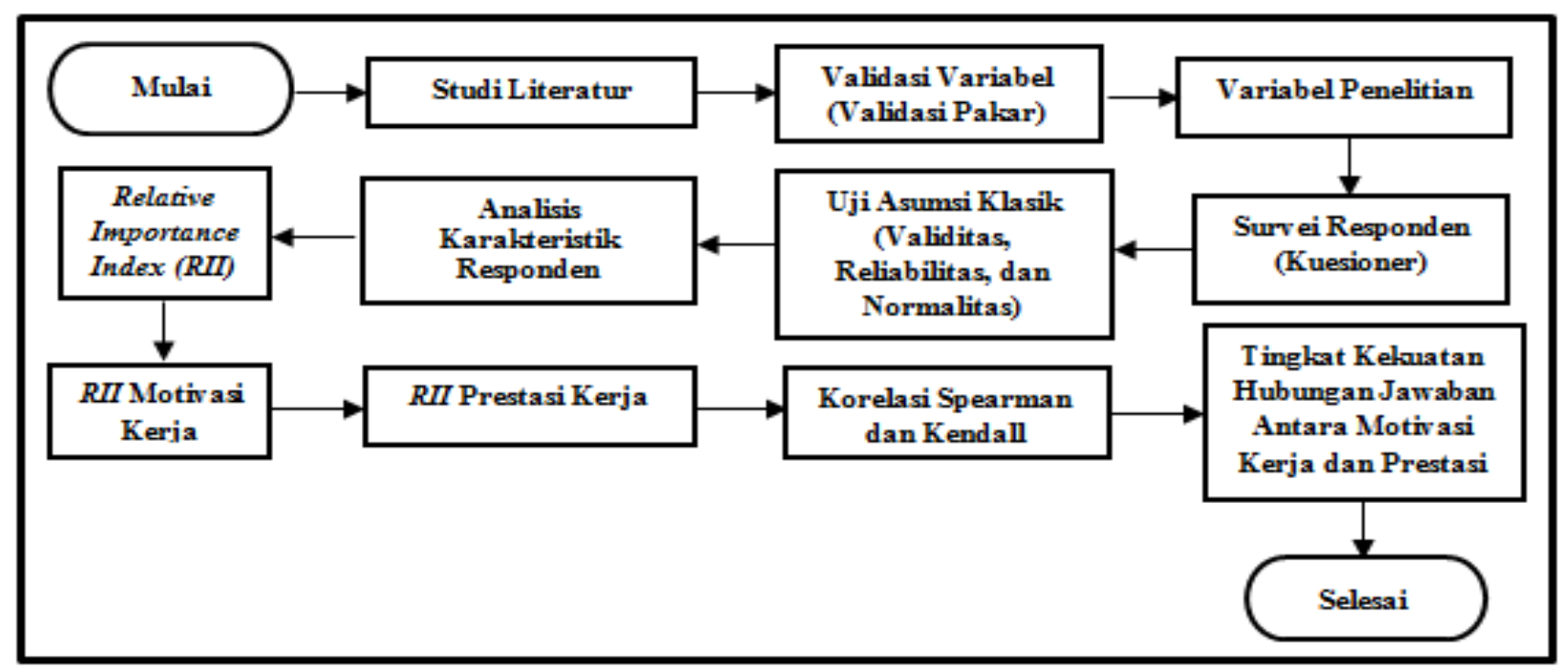

Gambar 1. Metode Analisis Data

Menurut Hardjomuldjadi (2009), analisis Relative Importance Index (RII) adalah suatu analisis yang memungkinkan suatu kuantitatif relatif, di mana semakin tinggi peringkat (rating) semakin tinggi pula pengaruh yang diberikan oleh variabel yang dimiliki. Rumus yang digunakan adalah:

$$
R I I=\frac{\sum W}{A \cdot N}
$$

Keterangan:

RII = Relative Importance Index

$\mathrm{W}=$ Bobot yang diberikan untuk faktor penyebab dominan (1,2,3,4 dan 5)

A $\quad=$ Bobot tertinggi (dalam penelitian ini adalah 5)

$\mathrm{N} \quad=$ Jumlah total responden 
Dalam penelitian ini, faktor prioritas motivasi dan prestasi kerja tenaga konstruksi Negara Timor Leste ditentukan melalui masing-masing 5 nilai variabel teratas motivasi dan prestasi kerja berdasarkan peringkat RII.

Analisis korelasi yang dipakai adalah analisis statistik korelasi non-parametrik, dengan uji Spearman dan Kendall. Metode korelasi rank correlation coefficient ditemukan oleh Carl Spearman pada tahun 1904 (Narbuko dan Achmadi, 2001). Dalam penelitian ini, uji korelasi Spearman dan Kendall bertujuan untuk mengetahui kekuatan hubungan antara hasil peringkat RII dari jawaban motivasi kerja dengan peringkat RII dari jawaban prestasi kerja. Jika terbukti adanya korelasi, maka penelitian dianggap cukup akurat.

\section{HASIL DAN PEMBAHASAN}

\section{Uji Instrumen Data}

Berdasarkan uji validitas, reliabilitas, dan normalitas data yang telah dilakukan, maka diperoleh kesimpulan:

1. Keseluruhan item variabel memenuhi persyaratan validitas data.

2. Keseluruhan item variabel memenuhi persyaratan reliabilitas data.

3. Data yang diperoleh merupakan data yang tidak terdistribusi normal, sehingga statistik yang dipakai adalah statistik non-parametrik.

\section{Karakteristik Responden}

Karakteristik responden didapatkan dari hasil jawaban responden pada bagian informasi data responden dari jumlah keseluruhan responden. Karakteristik responden dikelompokkan atas jenis kelamin, pengalaman kerja, tingkat pendidikan, Kualifikasi kompetensi keahlian, dan jabatan kerja pada perusahaan. Adapun data-data tersebut dijelaskan pada tabel 3 berikut:

Tabel 2.

\section{Persentase Karakteristik Responden}

\begin{tabular}{|c|c|c|c|c|c|c|}
\hline \multirow{3}{*}{$\begin{array}{c}\text { No } \\
1\end{array}$} & \multicolumn{2}{|c|}{ Karakterisik Responden } & \multicolumn{2}{|c|}{ Frekuensi } & \multicolumn{2}{|c|}{ Persentase (\%) } \\
\hline & Jenis kelamin & Pria & 38 & & 84.44 & \\
\hline & 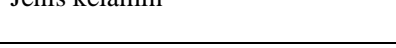 & Wanita & 7 & 45 & 15.56 & 100.00 \\
\hline \multirow{4}{*}{2} & \multirow{4}{*}{ Pengalaman Kerja } & $<5$ & 22 & & 48.89 & \\
\hline & & $6-10$ & 18 & & 40.00 & \\
\hline & & $11-15$ & 5 & & 11.11 & \\
\hline & & $>16$ & 0 & 45 & 0.00 & 100.00 \\
\hline \multirow{5}{*}{3} & \multirow{5}{*}{ Pendidikan } & SMA & 0 & & 0.00 & \\
\hline & & D3 & 6 & & 13.33 & \\
\hline & & S1 & 35 & & 77.78 & \\
\hline & & S2 & 4 & & 8.89 & \\
\hline & & S3 & 0 & 45 & 0.00 & 100.00 \\
\hline \multirow{2}{*}{4} & \multirow{2}{*}{ Kualifikasi Kompetensi Keahlian } & Bersertifikat & 2 & & 4.44 & \\
\hline & & Tidak bersertifikat & 43 & 45 & 95.56 & 100.00 \\
\hline \multirow{4}{*}{5} & \multirow{4}{*}{ Jabatan } & PM & 3 & & 6.67 & \\
\hline & & SE & 13 & & 28.89 & \\
\hline & & Supervisor & 23 & & 51.11 & \\
\hline & & SM & 6 & 45 & 13.33 & 100.00 \\
\hline
\end{tabular}




\section{Relative Importance Index (RII)}

Berdasarkan analisis relative importance index (RII), didapatkan faktor-faktor prioritas motivasi dan prestasi kerja tenaga konstruksi Negara Timor Leste, seperti yang ditunjukkan pada tabel 4 di bawah ini:

\section{Tabel 3.}

Relative Importance Index (RII) motivasi kerja dan pretasi kerja

\begin{tabular}{|c|c|c|c|c|}
\hline No & Faktor & & Variabel & Persentase \\
\hline \multirow[b]{4}{*}{1} & \multirow[b]{4}{*}{$\begin{array}{c}\text { Prestasi } \\
\text { kerja }\end{array}$} & $\mathrm{X} 5$ & $\begin{array}{l}\text { Kemampuan teknis: ilmu pengetahuan yang dimiliki, metode, teknik, dan peralatan yang } \\
\text { dipergunakan. }\end{array}$ & $73.78 \%$ \\
\hline & & $\mathrm{X} 21$ & Pengalaman kerja (experience is the best of teacher). & $73.78 \%$ \\
\hline & & $\mathrm{X} 8$ & $\begin{array}{l}\text { Kualitas kerja: dilihat dari akurasi, ketelitian dan kerapian karyawan dalam melaksanakan } \\
\text { tugas pekerjaan, mempergunakan dan memelihara alat-alat kerja, keterampilan dan } \\
\text { kecakapan. }\end{array}$ & $73.33 \%$ \\
\hline & & $\mathrm{X} 9$ & $\begin{array}{l}\text { Kuantitas kerja: dilihat dari volume keluaran (output), target kerja dalam kuantitas dan } \\
\text { kontribusi lain seperti menyelesaikan pekerjaan tambahan berupa penambahan jam kerja } \\
\text { (lembur). }\end{array}$ & $72.00 \%$ \\
\hline
\end{tabular}

Kerajinan: kemampuan karyawan dalam melaksanakan tugas diluar pekerjaannya maupun adanya tugas baru, kecakapan berpikir dan bertindak sebelum bekerja serta tingkat disiplin $\quad 71.56 \%$ dalam menjalankan tugas dan kemampuan dalam mengeluarkan inisiatif.

\begin{tabular}{|c|c|c|c|c|}
\hline \multirow{5}{*}{\multicolumn{2}{|c|}{$\begin{array}{l}\text { Motivasi } \\
\text { kerja }\end{array}$}} & X31 & $\begin{array}{l}\text { Sistem imbalan yang diterima, imbalan merupakan karakteristik atau kualitas dari objek } \\
\text { pemuas yang dibutuhkan oleh seseorang yang dapat mempengaruhi motivasi atau dapat } \\
\text { mengubah arah tingkah laku dari satu objek ke objek lain yang mempunyai nilai imbalan } \\
\text { yang lebih besar. }\end{array}$ & $75.11 \%$ \\
\hline & & X32 & $\begin{array}{l}\text { Kebutuhan (need),melakukan aktivitas (kegiatan) karena adanya faktor-faktor kebutuhan } \\
\text { baik biologis maupun psikologis }\end{array}$ & $74.22 \%$ \\
\hline & & X34 & $\begin{array}{l}\text { Minat, minat adalah suatu rasa lebih suka dan rasa keinginan pada suatu hal tanpa ada yang } \\
\text { menyuruh. }\end{array}$ & $74.22 \%$ \\
\hline & & X28 & $\begin{array}{l}\text { Harapan-harapan akan masa depan. Harapan ini merupakan informasi objektif dari } \\
\text { lingkungan yang mempengaruhi sikap dan perasaan subjektif seseorang. Harapan } \\
\text { merupakan tujuan dari perilaku. }\end{array}$ & $73.78 \%$ \\
\hline & & X54 & $\begin{array}{l}\text { Tidak menyukai pekerjaan, mereka harus dipakai, dikendalikan, atau diancam dengan } \\
\text { hukuman untuk mencapai tujuan }\end{array}$ & $73.78 \%$ \\
\hline
\end{tabular}

\section{Korelasi Spearman dan Kendall}

Berdasarkan analisis korelasi Spearman dan Kendall, dapat diketahui hubungan keterikatan antara kedua variable berdasarkan peringkat- peringkat. Tabel 5 menunjukkan hasil analisis korelasi Spearman dan Kendall. Dari output dapat diketahui bahwa korelasi antara prestasi kerja dan motivasi kerja tenaga konstruksi Negara Timor Leste didapat nilai koefisien korelasi sebesar 0,935 dan 0,979 . Angka ini positif, menunjukkan terjadi hubungan positif, artinya semakin tinggi motivasi kerja maka prestasi kerja tenaga konstruksi juga semakin meningkat. Nilai 0,935 juga menunjukkan besarnya koefisien korelasi, dan dapat disimpulkan bahwa hubungan sangat kuat karena berada pada rentang 0,80 - 0,1000. 
Tabel 4.

Korelasi Spearman dan Kendall

\begin{tabular}{|c|c|c|c|c|}
\hline & & & PRESTASI & MOTIVASI \\
\hline \multirow{6}{*}{$\begin{array}{l}\text { Kendall's } \\
\text { tau_b }\end{array}$} & \multirow{3}{*}{ PRESTASI } & Correlation Coefficient & 1 & $.935^{* *}$ \\
\hline & & Sig. (2-tailed) & . & 0 \\
\hline & & $\mathrm{N}$ & 21 & 21 \\
\hline & \multirow{3}{*}{ MOTIVASI } & Correlation Coefficient & $.935^{* *}$ & 1 \\
\hline & & Sig. (2-tailed) & 0 & . \\
\hline & & $\mathrm{N}$ & 21 & 35 \\
\hline \multirow{6}{*}{$\begin{array}{l}\text { Spearman's } \\
\text { rho }\end{array}$} & \multirow{3}{*}{ PRESTASI } & Correlation Coefficient & 1 & $.979^{* *}$ \\
\hline & & Sig. (2-tailed) & . & 0 \\
\hline & & $\mathrm{N}$ & 21 & 21 \\
\hline & \multirow{3}{*}{ MOTIVASI } & Correlation Coefficient & $.979^{* *}$ & 1 \\
\hline & & Sig. (2-tailed) & 0 & . \\
\hline & & $\mathrm{N}$ & 21 & 35 \\
\hline
\end{tabular}

\section{KESIMPULAN DAN SARAN}

\section{Kesimpulan}

Berdasarkan hasil penelitian dan pembahasan yang dilakukan, didapatkan faktor-faktor yang mempengaruhi motivasi kerja dan prestasi kerja tenaga konstruksi Negara Timor Leste.

1. Terdapat beberapa faktor-faktor prioritas prestasi kerja tenaga konstruksi Negara Timor Leste yaitu, kemampuan teknis, pengalaman kerja, kualitas kerja, kuantitas kerja dan kerajinan. Sedangkan faktor-faktor prioritas motivasi kerja yaitu sistem imbalan yang diterima, kebutuhan (biologis maupun psikologis), minat, harapan-harapan akan masa depan dan dikendalikan dengan adanya hukuman.

2. Terdapat beberapa rekomendasi solusi untuk meningkatkan motivasi dan prestasi kerja tenaga konstruksi di Negara Timor Leste, faktor-faktor untuk meningkatkan prestasi kerja adalah:

a. Kemampuan teknis yaitu seorang tenaga kerja konstruksi di dalam organisasinya harus mampu dalam penguasaan terhadap metode kerja yang ada.

b. Pengalaman kerja, dengan adanya pengalaman bekerja maka telah terjadi proses penambahan ilmu pengetahuan dan keterampilan serta sikap pada diri seseorang, sehingga dapat menunjang dalam mengembangkan diri dengan perubahan yang ada.

c. Kualitas kerja yaitu seorang tenaga kerja konstruksi dalam melaksanakan tugastugasnya harus menunjukkan tingkat akurasi, ketelitian dan kerapian dalam melaksanakan tugas pekerjaan, mempergunakan dan memelihara alat-alat kerja, keterampilan dan kecakapan.

d. Kuantitas kerja yaitu pekerjaan yang dikerjakan oleh seorang tenaga konstruksi dalam suatu periode yang telah ditentukan. Kuantitas kerja yang dimaksud dapat dilihat dari volume keluaran (output), target kerja dalam kuantitas dan kontribusi lain seperti menyelesaikan pekerjaan tambahan berupa penambahan jam kerja (lembur).

e. Kerajinan yaitu kemampuan seorang tenaga kerja konstruksi dalam melaksanakan tugas diluar pekerjaannya maupun adanya tugas baru, kecakapan berpikir dan bertindak 
sebelum bekerja serta tingkat disiplin dalam menjalankan tugas dan kemampuan dalam mengeluarkan inisiatif.

Adapun faktor-faktor untuk meningkatkan motivasi kerja yang dapat diterapkan untuk meningkatkan penggunaan tenaga kerja lokal di Timor Leste adalah:

a. Imbalan, sistem imbalan yang dirancang oleh suatu organisasi harus mampu memacu motivasi kerja dari anggota organisasi agar berprestasi pada tingkat yang tinggi, untuk itu imbalan yang dibentuk harus memiliki nilai di mata anggota organisasi.

b. Kebutuhan ialah keinginan manusia akan barang dan jasa yang menuntut untuk dipenuhi, agar kelangsungan hidup manusia terjamin. Kebutuhan manusia beraneka ragam sehingga untuk memenuhi kebutuhannya bisa melakukan secara individu atau kelompok.

c. Minat yaitu rasa suka terhadap suatu pekerjaan dan keinginan untuk melakukan suatu pekerjaan tanpa ada yang menyuruh.

d. Harapan akan masa depan, setiap tenaga konstruksi tentu memiliki impian dan harapan akan masa depan mereka. Sehingga perlukan motivasi dan semangat yang tinggi serta kerja keras untuk mewujudkan masa depan tersebut.

e. Tidak menyukai pekerjaan (harus diancam dengan hukuman), sanksi hukuman berperan penting dalam memelihara kedisiplinan tenaga kerja konstruksi. Dengan sanksi hukuman yang semakin berat, maka semakin takut untuk melanggar peraturan-peraturan perusahaan, sikap dan perilaku indisipliner juga akan semakin berkurang.

3. Terdapat cara untuk memperbanyak penggunaan tenaga kerja lokal di Negara Timor Leste berdasarkan faktor motivasi dan prestasi kerja dengan cara melibatkan pemerintah baik secara langsung maupun tidak langsung dengan memberikan bantuan berupa dana kepada perusahaan untuk diadakan pelatihanan-pelatihanan kepada para tenaga kerja lokal guna meningkatkan kualitas dan kemampuan teknis sesuai dengan di bidangnya masing-masing. Adapun kebijakan-kebijakan yang harus dibuatkan oleh pemerintah untuk mengutamakan penggunaan tenaga kerja lokal dibanding tenaga asing.

\section{Saran}

Berdasarkan hasil penelitian dan kesimpulan diatas, maka diajukan beberapa saran sebagai berikut:

1. Penelitian ini diharapkan dapat memberikan kontribusi kepada berbagai pihak yang terkait (pemerintah dan perusahaan) untuk memperbanyak penggunaan tenaga kerja lokal berdasarkan motivasi kerja dan prestasi kerja.

2. Penelitian ini diharapkan dapat dijadikan acuan dan bahan evaluasi penelitian selanjutnya untuk proyek pembangunan infrastruktur yang berbeda, serta lingkup penelitian dapat diperluas pada wilayah- wilayah lainnya.

\section{REFERENSI}

Arikunto, S. (2003). Prosedur Penelitian, Suatu pendekatan Praktik. Jakarta: Rineka Cipta. Ervianto, W. I. (2005). Manajemen Proyek Konstruksi. Yogyakarta: Andi.

Halim, S \& W. Saidi (2007). Modul Perkuliahan Manajemen Sumber Daya Manusia. Jakarta: Unit Layanan Psikologi PKMT Press.

Hardjomuljadi, S. \& N. Wahyudi (2009). Kendala Serah Terima Proyek Konstruksi Antara DitJen Cipta Karya Dengan Pemerintah Daerah. Bandung: Universitas Katolik Parahyangan.

Hariandja, M. T. E. (2002). Manajemen Sumber Daya Manusia. Jakarta: Grasindo. 
Hasibuan, M. S. (2008). Manajemen Sumber Daya Manusia. Cetakan ke-11. Jakarta: Bumi Askara.

Husnan, H. S. (2002). Manajemen Personalia. Yogyakarta: Gajah Mada Yogyakarta.

Mathis, R. L. \& J. H. Jackson (2001). Manajemen Sumber Daya Manusia. Jakrata: Salemba empat.

Narbuko, C. \& A. Achmadi (2001). Metode Penelitian. Jakarta: Bumi Aksara

Notoatmodjo, S. (2007). Pendidikan dan Perilaku kesehatan. Jakarta: Rineka Cipta.

Pujadi, A. (2007). Faktor Faktor Yang Mempengaruhi Motivasi Belajar Mahasiswa,Jurnal Bunda Mulia Volume 3 No. 2. Jakarta: Fakultas ekonomi Universitas Sumatera Utara.

Robins, S. P. \& T. A. Judge (2007). Perilaku Organisasi. Jakrata: Salemba Empat.

Siagian, S. P.. (2008). Manajemen Sumber Daya Manusia. Jakarta: Bumi Askara.

Simamora, H. (2004). Manajemen Sumber Daya Manusia, Edisi Ketiga. Yogyakarta: STIE YKPN.

Subri, M. (2003). Ekonomi Sumber daya Manusia Dalam Perspektif Pembangunan. Jakarta: Raja Grafindo Persada.

Uno, H. B. (2007). Teori Motivasi dan pengukurannya Analisis di Bidang Pendidikan. Jakarta: Bumi Askara.

Wahyudi, B. (2002). Manajemen Sumber Daya Manusia . Bandung: Sulita.

Wibowo. (2010). Manajemen Kinerja. Jakrata: Rajawali Press. 